\title{
Transcriptomic Assessment of Dietary Fish Meal Partial Replacement By Soybean Meal and Prebiotic Inclusion In The Liver of Juvenile Pacific Yellowtail (Seriola Lalandi)
}

Oscar E. Juárez ( $\nabla$ ojuarez.bio@gmail.com )

Centro de Investigacion Cientifica y de Educacion Superior de Ensenada https://orcid.org/0000-00028007-1671

\section{Rigoberto Delgado-Vega}

Centro de Investigacion Cientifica y de Educacion Superior de Ensenada Fabiola Lafarga De La Cruz

Centro de Investigacion Cientifica y de Educacion Superior de Ensenada Juan Pablo Lazo

Centro de Investigacion Cientifica y de Educacion Superior de Ensenada Edgar López-Landavery

Centro de Investigacion Cientifica y de Educacion Superior de Ensenada

Dariel Tovar

Centro de Investigaciones Biologicas del Noroeste SC

Clara E. Galindo-Sánchez

Centro de Investigacion Cientifica y de Educacion Superior de Ensenada

\section{Research Article}

Keywords: Fish meal replacement, Gene expression, Liver transcriptome, Pacific yellowtail, Prebiotic inclusion

Posted Date: April 13th, 2021

DOl: https://doi.org/10.21203/rs.3.rs-408448/v1

License: (c) (i) This work is licensed under a Creative Commons Attribution 4.0 International License. Read Full License 


\section{Abstract}

Seriola lalandi is an important species for aquaculture, due to its rapid growth, adaptation to captivity and formulated diets, and high commercial value. Due to the rise in fish meal (FM) price, efforts are made to replace it partially or entirely with vegetable meals in diets for carnivorous fish. The use of prebiotics when feeding vegetable meals has improved fish health. In this study, four experimental diets were assessed in juveniles, the control diet consisted of FM as the main protein source, the second diet included $2 \%$ GroBiotic $\circledast$-A (FM-P), the third included FM with $25 \%$ replacement by soybean meal (SM25), and the fourth consisted in SM25 with $2 \%$ of GroBiotic ${ }^{\circledR}-A$ (SM25-P). RNA-seq of the liver tissue was performed, followed by differential expression analysis and functional annotation to identify genes affected by the diets. Growth was not affected by this level of FM replacement, but it was improved by the prebiotic. Annotation was achieved for 78,826 transcripts, of which 135 were up-regulated and 78 down-regulated among all treatments compared to the control. Transcriptomic profiles of control samples were clustered with those from fishes fed SM25 and SM25-P diets, and the most differentiated group was that one fed the FM-P diet. SM25-P showed the least amount of differentially expressed genes, maintaining general transcriptomic profiles of control diet in the liver, therefore this diet is a potential economic alternative to the FM diet, for $S$. Ialandi juveniles. Assessment of the effects of this diet along the digestive tract is recommended.

\section{Introduction}

The Pacific yellowtail Seriola lalandi is a pelagic marine fish of the perciform order of the Carangidae family, which is distributed worldwide in temperate and subtropical waters [1] ranging from 18 to $24^{\circ} \mathrm{C}$ [2-4]. It feeds mainly on mackerel, anchovy, sardine, and squid [2] and can grow up to $2.5 \mathrm{~m}$ long and weigh up to $70 \mathrm{~kg}$ [5]. It is an important species for commercial and recreational fishing in Japan, Australia, and New Zealand [6]. S. Ialandi is a commercially important species for aquaculture because it grows rapidly, adapts well to captivity, accepts formulated diets, and has an excellent acceptance in the market and high commercial value due to the quality of its meat [7]. One of the key aspects for the successful culture of this species is adequate feeding and nutrition, which depends on the quality and source of the ingredients that make up the diet [2]. Fish meal is the primary source of protein in diets for carnivorous fish. This ingredient has a high digestibility and an excellent amino acid profile [8]. However, because it is a limited resource, in the last years the costs have increased dramatically, and its availability has decreased since its global production has not increased to meet the demands of the aquaculture industry [9]. Replacing fish meal with alternative protein sources helps to optimize production costs. In this sense, several studies have been performed to replace fish meal with vegetable meals $[10,11]$. Soybean meal (SBM) has a good balance of essential amino acids and an excellent nutritional composition at a reasonable price, it is widely used to replace fish meal [12]. However, it should be considered that SBM has several antinutritional factors (ANFs) [13]. Besides, when fed to carnivorous fish SBM can cause intestinal damage leading to enteritis [10] and the ANFs produced by plants as a defense 
mechanism against animals can alter the biochemical, physiological, or immunological response of the animals fed with SBM [14-16].

The use of prebiotics in the diets of fish has emerged as an alternative to reduce the adverse effects of alternative proteins such as SBM-based formulated diets [17-19]. Some commercial products containing prebiotics have recently been evaluated with interesting results in fish such as Previda ${ }^{\mathrm{T}}{ }^{\mathrm{M}}$, Bio-MOS ${ }^{\circledR}$, and GroBiotic $\AA-A$ [20-22]. Prebiotics are indigestible carbohydrates used as food ingredients that beneficially affect the host, by stimulating the growth and activating the metabolism of the health-promoting bacteria in the digestive tract [23]. GroBiotic ${ }^{\circledR}-\mathrm{A}$ is a widely used prebiotic in aquaculture, which consists of a mixture of brewer's yeast and dry fermentation products. It is composed of several polysaccharides, one of which, $\beta$-glucan is known to induce positive immunological responses in fish [24]. It has been reported that in juvenile hybrid striped bass (Morone chrysops $\times$ Morone saxatilis) the inclusion of GroBiotic $\AA-A$ in the diet, improved respiratory burst and resistance against infection with Streptococcus iniae and showed a significant increase in feed efficiency [18]. In another work, [19] authors reported an improved growth performance in hybrid striped bass fed a diet enriched with GroBiotic ${ }^{\circledR}-A$ and a general improvement in survival. Likewise, it was reported that when GroBiotic ${ }^{\circledR}-A$ was included in the diet, the apparent digestibility coefficients of protein and carbohydrate increased for red drum (Sciaenops occelatus) [17]. Other works have shown that prebiotics affect lipid and glucose metabolism in mammals, reducing hepatic lipogenesis, triglycerides levels, and cholesterol in serum and liver while improving glucose tolerance $[25,26]$.

Differences in diet composition promote changes in the levels of enzyme activities involved in the intermediary metabolism in the fish liver [27]. Metabolic factors, such as metabolite and enzymatic activity, are currently used to determine the capacity for metabolic adaptation to dietary supply in fish. In this regard, key liver enzyme activities of intermediary metabolism have been shown to match well with nutritional status and the growth rate of fish [28]. The liver is the primary metabolic organ of fish, being the center of the intermediary metabolism $[28,29]$. It is involved in the use of nutrients, plays an essential role in carbohydrate and lipid metabolism, synthesis of bile salts and most of the plasma proteins and hormones, and is the main energy storage. These features make the liver a reliable indicator in the evaluation of the nutritional condition, including energy metabolism, and an indicator of the state of the fish immune system [30-33]. Moreover, the liver has been the target organ to assess the effect of experimental diets on the physiological performance of fish [28, 29, 31, 34-43]. However, very few studies have evaluated the effect of diets on fish liver physiology at gene expression and transcriptomic levels $[29,42]$.

In this study, the effects of three experimental diets on the liver physiology of juveniles were evaluated using a transcriptomic approach by implementing the RNA-seq technology. The present work aims to identify which genes were affected in their expression levels due to the inclusion in the diet of SBM, the prebiotic, and their combination, making emphasis on key biological processes like carbohydrate metabolism, lipid metabolism, growth, and the immune response. 


\section{Material And Methods}

\subsection{Experiment design and feeding trial}

The juveniles of Pacific yellowtail S. Ialandi used in this work came from Ejido Eréndira, Ensenada, B.C., Mexico, which were donated from the company Ocean Baja Labs. The feeding trial was conducted in the aquaculture department of the Center for Scientific Research and Higher Education of Ensenada (CICESE). Before the experiment, the fish were placed for 17 days in $3 \mathrm{~m}^{3}$ raceway ponds, then reared for 58 days in a $9 \mathrm{~m}^{3}$ pond where they reached the size of $97.9 \pm 8.5 \mathrm{~g}$. For the experimental trial, $180 \mathrm{fish}$ were randomly taken and distributed in 12 tanks at a rate of 15 organisms per tank. The tanks consisted of circular fiberglass ponds with a capacity of $500 \mathrm{~L}$, with a flat bottom, a biofilter with Kapdes type aeration, with a volume of $350 \mathrm{~L}$, a compensation tank of $275 \mathrm{~L}$, and two water pumps (Sweetwater High efficiency She 3.0 Aquatic Eco-Systems and an Aqua Logic heat pump model 2TWB0018A1000AB). In experimental tanks, dissolved oxygen was maintained between $5-7 \mathrm{mg} / \mathrm{L}$, the temperature at $23.5 \pm 1{ }^{\circ} \mathrm{C}$, and total ammoniacal nitrogen below $0.05 \mathrm{mg} / \mathrm{L}$. The fish were in a 12-day acclimatization period in the new culture system, where they fed the commercial diet for marine fish (Skretting: 55\% protein and 15\% lipids), three times a day $(8: 00,12: 00$, and 16:00 h). The feeding trial was conducted to evaluate the effect of including a commercial prebiotic, GroBiotic ${ }^{\circledR}$-A, and the replacement of fish meal with SBM [44]. Four experimental diets were formulated (Table 1), the control diet consisted of fish meal as the main protein source (FM), the second diet was formulated with fish meal as the main protein source with the inclusion of $2 \%$ GroBiotic $\AA-A(F M-P)$, the third diet included fish meal with $25 \%$ replacement by SBM (SM25), and the fourth diet, fish meal with $25 \%$ replacement by SBM and the inclusion of $2 \%$ of GroBiotic ${ }^{\circledR}-A(S M 25-P)$. Each diet was supplied in three tanks (45 fish per diet); therefore, we had a $2 \times 2$ factorial design including two levels of FM replacement ( 0 and $25 \%)$ and two levels of prebiotic ( 0 and $2 \%$ ), with three replicates (three tanks). The fishes were fed daily to apparent satiation, at each feeding period, all the uneaten feed in each tank was removed after one hour from feeding and was dry weighed $(d w)$. Consumed feed was = total feed offered $d w-$ uneaten feed $d w$, in that feeding period. The consumed feed was divided by the number of alive fish per diet.

For growth analysis, all the fishes alive were measured on days $14,28,42$, and 56 . The thermal growth coefficient (TGC) [45] and feed conversion rate (FCR = ingested food dry weight/fish wet weight gained) were estimated for every interval between sampling dates. Then at the end of the study, these parameters were averaged to obtain mean values for the whole study and analyzed by two-way ANOVA with a statistical significance of $P<0.05$, using STATISTICA v.8.0. After 56 days of the experiment, the fish were first anesthetized by immersion in seawater with tricaine methanesulphonate (MS-222) $(90 \mathrm{mg} / \mathrm{L})$ and then euthanized through brain puncture. Then the livers were extracted and embedded in RNA later at $-80^{\circ}$ C until used for analysis.

\subsection{RNA extraction and sequencing}


For RNA sequencing, three biological replicates per diet were used for a total of twelve liver samples. Total RNA was extracted from 10 mg of every liver sample using the commercial kit Pure Link RNA mini kit (Invitrogen) following the manufacturer's instructions. The concentration and purity of the RNA were quantified using Qubit (Thermo Fisher Scientific, Waltham, USA). The integrity of the RNA was calculated with the 2100 Bioanalyzer capillary electrophoresis system (Agilent Technologies, Santa Clara, CA, USA). The synthesis of complementary DNA (CDNA) to build the sequencing libraries was performed for each sample using the Illumina TruSeq RNA Sample Preparation Kit v2, according to the manufacturer's instructions. Paired-end RNA sequencing was performed using the Illumina Hiseq 4000 platform at Roy J. Carver Biotechnology Center (University of Illinois, Urbana, IL, USA).

\subsection{Transcriptome assembly}

The quality of the sequencing reads was analyzed using the FastQC software, then adaptors, ambiguous nucleotides, and low-quality sequences were eliminated with the Trimmomatic- 0.36 software using a sliding window of 5 nucleotides and a minimum average quality of 28 in the Phred scale [46]. Finally, high-quality reads from all the libraries were assembled de novo using the Trinity v2.4.0 program with default parameters [47].

\subsection{Differential expression analysis}

The differential gene expression analysis was carried out using Bowtie2 [48] for the alignment of the reads and abundance estimation of the transcripts in each treatment, using the assembled transcriptome as reference. The quantification and normalization were performed using transcripts per million (TPM) through the RSEM program [49]. The expression analysis was performed using the TPM matrix of each treatment through DESeq2, comparing each treatment against the control diet [50] in R software [51]. In this analysis, the parameters of false discovery rate (FDR) were set below 0.01 with a fold change above 2. The results of the differential expression analysis were represented with heatmaps which were generated following the R scripts included in Trinity software [47]. Finally, the transcripts with differential expression between treatments versus the control were classified with Venn diagrams, using the Venny 2.1 platform (bioinfogp.cnb.csic.es/tools/venny/) [52].

\subsection{Functional annotation}

The functional annotation of the assembled transcriptome was carried out through the search of homologs with BLASTx [53] using the public databases UniProt (release 2019_2). The E value filter for this analysis was set at E-5. On the other hand, the annotation with terms of gene ontology (G0) was made with the Blast2GO program [54]; each GO was classified into the categories of biological processes, cellular components, and molecular functions. The enrichment analysis for down and up-regulated genes of each treatment versus the control was performed through Fisher's exact test (FDR <0.05) using the Blast2GO program. As well, the metabolic pathways from the Kyoto Encyclopedia of Genes and Genomes database (KEGG) were downloaded through DAVID 6.8 [55], using the up and down-regulated genes of each experimental diet. Additional enrichment analysis of biological processes and KEGG pathways was 
carried out for the reference transcriptome in DAVID 6.8 (P-value < 0.01). UniProt IDs from enriched KEGG pathways were analyzed in STRING software $[56,57]$, to visualize the protein-protein interactions of each pathway, using Homo sapiens and Danio rerio as models.

\section{Results}

\subsection{Growth performance}

The weight gained, and percent weight gained, resulted significantly higher due to the prebiotic. Besides, the thermal growth coefficient (TGC) was significantly higher in those fish fed with prebiotic. Additionally, no interaction was found between both factors (diet/prebiotic) and no significant differences were observed in the food consumed between treatments (Table 2).

\subsection{Sequencing and transcriptome assembly}

A total of 712,373,692 high-quality paired reads of 100 bp were obtained including all libraries, and a total of 155,247 contigs were assembled with an average length of $972 \mathrm{bp}$, an N50 of 1,722 bp, and a GC content of $47 \%$, in total $150,952,398$ bases were assembled.

\subsection{Differential gene expression}

In the differential expression analysis, the three experimental treatments against the control diet were compared. Results showed that a total of 135 genes were up-regulated in all treatments compared to the control. From these, 83 transcripts were up-regulated in the FM-P treatment, 30 up-regulated in the SM25$\mathrm{P}$ treatment, and 57 up-regulated in the SM25 diet. Of which 55 were exclusive to the FM-P treatment, 18 were exclusive to the SM25-P treatment, and 31 to the SM25 treatment. From all these transcripts, 4 were up-regulated in all the experimental treatments when compared to the control (Fig. 1A). A total of 78 transcripts were down-regulated in all the treatments, and none was shared among them. Of which, 35 were down-regulated in the FM-P treatment, 14 down-regulated in the SM25-P treatment, and 35 transcripts in the SM25 treatment. Where 33 were exclusive of the FM-P treatment, 9 transcripts were exclusive of the SM25-P treatment and 30 transcripts were exclusive of the SM25 treatment (Fig. 1B).

The biological replicates from all the diets were clustered based on the normalized expression values (TPM) of the up-regulated transcripts in the experimental diets, the up-regulated transcripts in the control diet, and selected transcripts with gene ontologies corresponding to carbohydrate metabolism, lipid metabolism, growth, and immune system. The heatmap of up-regulated transcripts in the treatments showed two main clusters, the first one containing the three replicates of the control diet in the same branch, and the sample SM25_1 in an adjacent branch; the second cluster contained the rest of the samples grouping those from SM25 and SM25-P with FM-P_1, and in an adjacent branch FM-P_2 and FM-P_3 were grouped (Fig. 2). The heatmap of up-regulated transcripts in the control showed three main clusters, the first one grouped two control samples with SM25-P_2; another grouped one control sample with two SM25 samples and SM25-P_3; and a third cluster grouped all three FM-P samples in the same 
branch, with SM25-P_1 and SM25_3 in adjacent branches (Fig. 3). Finally, the heatmap including transcripts with relevant functional annotation showed two main clusters, the first one grouped all control samples in the same branch with two SM25 and two SM25-P in adjacent branches; the second cluster grouped the three FM-P samples with SM25_3 and SM25-P_1 (Fig 4). All heatmaps clustered the control samples with samples of fish fed diets including SBM with and without prebiotic. Also, all heatmaps separated the control samples from FM-P samples. Transcriptomic profiles of control samples were more similar to those of fishes fed diets including SBM, with and without prebiotic and the most differentiated group was that one fed the FM-P diet. Annotations of relevant transcripts selected for cluster analysis are shown in Table 3.

\subsection{Functional annotation}

In the functional annotation through BLASTx, homologs were searched for the 155,247 contigs, and 58,167 matches were found with significant homology in the UniProt protein database, of which 51,609 had a gene ontology and functional annotation. The species with the highest number of homologies was Homo sapiens $(28,787)$, followed by Mus musculus $(15,788)$ and Danio rerio $(9,183)$. Other fish species with significant matches were Takifugu rubripes (432), Oncorhynchus mykiss (388), and Salmo salar (279). Based on the results of functional annotation, gene ontology (GO) terms of cellular component, molecular function, and biological processes were assigned. The most abundant terms in the cellular component category corresponded to intracellular part $(38,744)$, intracellular organelle $(32,680)$, and membrane-bounded organelle $(29,361)$. In the category of molecular function, the top terms were protein binding $(23,390)$, organic cyclic compound binding $(15,094)$, and ion binding $(14,913)$. Finally, in the category of biological processes, the most abundant terms were cellular metabolic process $(28,175)$, metabolic process of nitrogen compounds $(25,837)$, cellular component organization $(15,651)$, and biosynthetic process $(15,013)$.

\subsection{Enrichment analysis for biological process and metabolic pathways}

According to the functional annotations, important metabolic processes were enriched for the liver transcriptome like phospholipid biosynthetic process, steroid metabolic process, and protein transport, as well as the immune system process (Table 4). KEGG pathways were also enriched including phosphatidylinositol signaling system, inositol phosphate metabolism, aldosterone synthesis and secretion, mTOR signaling pathway, B cell receptor signaling pathway, thyroid hormone signaling pathway, glucagon signaling pathway, and insulin signaling pathway among others (Table 5). Proteinprotein interactions involved in the signaling pathways enriched in liver transcriptome are shown in Supplementary Figure S1 A-G.

In the FM-P treatment, metabolic GO terms like negative regulation of protein catabolic process and glucose metabolic process were enriched by upregulated-transcripts; by contrast, down-regulated transcripts enriched processes like cholesterol transport and signaling processes related to apoptosis and the Wnt signaling pathway. In the SM25-P treatment metabolic terms like tyrosine catabolic process, Lphenylalanine catabolic process, and fatty acid biosynthetic process were enriched by up-regulated 
transcripts; on the other hand, down-regulated transcripts enriched processes related to cholesterol transport, phospholipid homeostasis, phospholipid catabolic process, and the Wnt signaling pathway. Finally, in the SM25 treatment GO terms like gene silencing, response to bacterium, and protein dephosphorylation were enriched by up-regulated transcripts; inversely, down-regulated transcripts enriched processes like positive regulation of transcription, DNA-templated, and cell division (Table 6).

Based on the KEGG database, differentially expressed transcripts enriched the metabolic pathway category in FM-P. Besides, down-regulated transcripts in SM25 enriched the Rac 1 cell motility signaling pathway (Table 7).

\section{Discussion}

In this study, we analyzed the liver gene expression of the Pacific yellowtail $S$. lalandi juveniles fed with diets containing different protein sources, with and without a prebiotic. The study was focused on the liver because it is the main organ involved in the use of nutrients and is the center of intermediary metabolism in animals [32]. Moreover, it is important for fatty acids metabolism, lipid storage and is the main responsible for glucose homeostasis by regulating both gluconeogenesis and glycolysis processes $[58,59]$.

Regarding the experimental diets, the level of FM replacement by SBM tested in this study (25\%) was high, considering that up to $20 \%$ is the recommended FM replacement level using SBM or soy protein concentrate for juveniles $[60,61]$ and that inclusion of $30 \%$ or higher of SBM in diets have resulted detrimental for this species $[62,63]$. Although the level of FM replacement was high, it did not affect fish growth. Interestingly, the inclusion of prebiotic in diets with and without FM replacement improved the growth. Therefore, this replacement level using SBM when combined with GroBiotic®-A is a good balance between cost and benefit for $S$. lalandi juveniles.

In the transcriptomic analysis, we distinguished differentially expressed genes (DEGs) potentially involved in metabolic pathways, growth, and the immune system. DEGs were more abundant in fish fed with FM-P diet, followed by SM25. On the other hand, SM25-P showed the least amount of DEGs. This suggests that the prebiotic in SM25-P compensated the general effect of SBM on the transcriptome, by keeping the expression of most of the genes at the same level as the control diets. Moreover, the cluster analyses based on the general transcriptomic profile grouped fish fed both diets including SBM with those fed the control diet, suggesting a similar physiologic performance of the liver in fish fed SM25, SM25-P, and control diets. The effect of diets on specific metabolic processes is discussed below.

\section{Growth}

Regarding the effect of the diets on growth, fishes fed with FM-P and SM25-P diets resulted in the highest percentage of weight gain, the greatest weight gain in grams and TGC [44]. Pacific yellowtail is a fastgrowing fish as was observed with these results, which coincide with those obtained for S. Ialandi juveniles fed diets formulated with vegetable ingredients [64]. In our analysis, we observed an up- 
regulation of the TGFBR3 gene, in the FM-P diet. This gene expression pattern showed a significant association with the FCR in chickens [65]. Moreover, this gene has a great interest in aquaculture because is important for muscle growth in rainbow trout Oncorhynchus mykiss [66]. On the other hand, in a genome-wide association study to identify molecular markers associated with growth in the Atlantic salmon Salmo salar, genes including the TGFBR3 showed strong correlation with growth [67]. Another upregulated gene in the FM-P treatment was the epidermal growth factor receptor kinase substrate 8 (EPS8). According to [68], the transcriptomic profiles of red and white carps were compared to identify differential gene expression and found up-regulated genes associated with muscle development, including the EPS8. By contrast, this gene was down-regulated in SM25, versus the control diet. However, the mTOR gene, which is also related to growth, was up-regulated in the SM25 diet in our study. This gene, both in rainbow trout and in mammals, promotes protein accumulation in skeletal muscle by the effect of adequate feeding [69]. Integrating physiological data measured in [44] with the transcriptomic data analyzed herein, it is considered that the diets including prebiotic (FM-P and SM25-P) can improve growth, as both diets induced a higher weight gain and more genes related to growth.

\section{Carbohydrate metabolism}

One of the main metabolic processes affected by the experimental diets was carbohydrate metabolism. Carbohydrate requirement in fish varies according to the feeding habits of the species, ranging from herbivorous to strict carnivores; despite this, glycolysis is an important metabolic pathway to provide energy to maintain cellular activities [70]. The capability of the liver to maintain the balance between the intake and release of glucose plays an essential role in the maintenance of the homeostasis of glucose in the blood [71]. Regarding carbohydrate metabolism, no differences were found in the amylase activity between diets [44]; however, in our transcriptomic analysis, both diets with SBM, showed high expression of the H6PD gene, and in the SM25 diet the 6-phosphofructo-2-kinase/fructose-2,6-bisphosphatase 4 (PFKFB4) gene was up-regulated. The enzyme encoded by this gene can reduce hepatic glucose production by increasing glycolysis and inhibiting gluconeogenesis, thereby lowering blood glucose [71]. On the other hand, in the European seabream Sparus aurata, it was found that fishes fed diets with high carbohydrate content, resulted in the up-regulated expression of the PFKFB4 gene [72]. Authors conclude that the expression of PFKFB4 helps carnivorous fish to adapt to diets with the inclusion of plant meals. In the case of the FM-P diet, it was evident that the glucose metabolism was up-regulated with high expression of G6PD y H6PD genes, both participating in glucose oxidation [73, 74]. Additionally, the protein phosphatase 1 regulatory subunit $3 \mathrm{C}$ (ppp1 $3 \mathrm{cb}$ ), which limits the breakdown of glycogen [75] was down-regulated. Moreover, protein catabolism was also down-regulated, suggesting that this diet enhanced glycolysis, and the energy supply obtained through this pathway was enough to reduce gluconeogenesis, improving protein weight gain. By contrast, in SM25-P, fatty acid biosynthesis was upregulated, suggesting that in this diet the observed weight gain could be also related to lipid accumulation.

\section{Lipid metabolism}


A better understanding of the physiological mechanisms of lipid metabolism of fishes is critical to replace fish meal and fish oil in formulated diets, and if combined with gene expression studies would allow the identification of genes and potential markers for fish selection. According to our annotation and enrichment analysis, many genes involved in lipid metabolism were identified, as the ATP8A2 gene, which is up-regulated in human adipocytes [76]. This gene (ATP8A2) participates in the asymmetric distribution and translocation of phospholipids and seems to be involved in the formation of vesicles and the uptake of lipid signaling molecules [77]. In our study, ATP8A2 was up-regulated in diets including SBM (SM25-P and SM25), which can tell us about an effort by fish to maintain balance in the distribution of lipids due to SBM inclusion in the diet. On the other hand, no differences were found in the amount of lipid accumulated in the muscle of the fish [44]. High expression of ATP8A2 can be suggested as a molecular marker of fishes adapting to vegetable diets. Other genes with differential expression in the experimental diets were $L I P G$ and $L P I N 2$. $L I P G$ gene, which participates in the hydrolysis of high-density lipoproteins [78] was down-regulated in fish fed SM25-P diet; and LPIN2, which plays an important role in the control of the metabolism of fatty acids at different levels [79], was up-regulated in the FM-P diet. The transcriptomic analysis of the intestinal mucosa of the sea bass (Dicentrarchus labrax) fed with low fishmeal diets showed that LPIN2 was up-regulated in fishes fed diet with the highest percentage of fishmeal [80]. However, in this study, this was observed only when the prebiotic was added to the fishmeal since the LPIN2 gene had the highest expression level in the FM-P diet. Considering the mentioned above, experimental diets induced changes in the expression levels of genes related to lipid metabolism in the liver. However, it is necessary to evaluate the expression and activity of pancreatic and intestinal lipases in future work, to have a clearer view of the effects of diets with the inclusion of SBM and prebiotics.

\section{Immune response}

Finally, another relevant process affected by the experimental diets was the immune response. The immune system in fish is an important mechanism and the first line for protection against pathogens [81]. It should be noted that in this species, the leukocytes had a significant decrease in fish fed diets that contain prebiotic [44]. In this work, we found differential expression of genes with potential participation in the immune response. For example, the B-cell receptor $C D 22$ gene $(C D 22)$ was up-regulated in the FM-P diet, this gene seems to be involved in the regulation of B-cell antigen receptor signaling, mediates B-cellB-cell interactions, and may be involved in the localization of B-cells in lymphoid tissues [82, 83]. In a transcriptomic analysis of the grass carp (Ctenopharyngodon idellus) infected with Aeromonas hydrophila the $C D 22$ was up-regulated [84]. Another up-regulated gene in the FM-P diet was serine/threonine-protein kinase $R I O 3$ (RIOK3), which plays a critical role in the innate immune response against DNA and RNA viruses [85]. In our work we found RIOK3 up-regulated in fish fed with the FM-P diet. On the other hand, Caspase-1 (CASP1) was down-regulated in fish fed with the SM25 diet. CASP1 is important for defense against pathogens and is involved in a variety of inflammatory processes. In a nutritional experiment with gilthead seabream (Sparus aurata), gene expression of CASP1 increased in fishes fed with the diets that include the probiotic bacterium Bacillus subtilis [86]. Another important gene for the immune response, the complement component C9 (C9) was found up-regulated in SM25-P. This gene plays a key role in the innate and adaptive immune response by forming pores in the plasma 
membrane of target cells [87]. The expression of C9 was detected in the spleen, stomach, intestine, and head kidney, with the highest levels detected in the liver of the southern catfish (Silurus meridionalis) [88]. On the other hand, evaluations in Larimichthys crocea under a Vibrio alginolyticus challenge, showed that two components of the terminal complement system: $\mathrm{C} 7$ and $\mathrm{C} 9$, were expressed in many tissues in adult healthy fish, with the highest levels detected in liver [89]. Moreover, SM25 and SM25-P showed upregulation of the $\mathrm{C} 3$ gene, involved in inflammatory processes and response to bacteria [90], but it is also involved with glucose transport related to diabetes [91, 92].

\section{Recommendations}

Based on the overall results, the FM-P diet was the best, since fish fed this diet showed a better physiological response, especially considering the growth rate, as well as the expression pattern of metabolic and immune genes in the liver. However, this diet may increase production costs. Although $25 \%$ of fish meal replacement by SBM did not affect growth, the SM25 diet was the one with less upregulation of growth-related genes and more down-regulated genes related to the immune system. Interestingly, the prebiotic inclusion in diets with and without SBM improved the growth rate and physiologic performance of the liver. In the SM25-P diet, the prebiotic seems to compensate for the effect of SBM on the liver at the transcriptomic level since the overall gene expression in fish fed this diet was maintained at similar levels as those of the control diet.

The results of this work and together with those of [44], suggest that up to $25 \%$ of fish meal can be substituted with SBM combined with the prebiotic. However, it is necessary to evaluate the response of the fish for a longer period, to test long-term effects in growth, physiologic performance, immune response, and meal quality in adult organisms, and evaluate the effect of this diet on other tissues of the digestive tract.

\section{Declarations}

\section{Funding}

This work was funded by the Consejo Nacional de Ciencia y Tecnología (CONACYT, México) through the Centro de Investigación Científica y Educación Superior de Ensenada, Baja California (CICESE) internal projects 682136 and 623159 .

\section{Conflicts of interest/Competing interests}

Authors declare that no competing interests or conflicts of interest exist.

\section{Authors' contribution}

OEJ: Conceptualization, Formal analysis, Visualization, Writing - original draft.

RDV: Data curation, Formal analysis, Visualization, Writing - original draft. 
FLDC: Conceptualization, Methodology, Resources, Supervision, Writing - review and editing.

JPL: Conceptualization, Methodology, Investigation, Resources, Funding acquisition, Supervision, Writing - review and editing.

ELL: Data curation, Formal analysis, Writing - review and editing.

DTR: Conceptualization, Methodology, Supervision, Writing - review and editing.

CEGS: Conceptualization, Methodology, Resources, Funding acquisition, Supervision, Writing - review and editing.

\section{Ethics approval}

This research complied with the Guidelines of the European Union Council (2010/63/EU) and the Mexican Government (NOM-062-Z0O-1999) for the production, care, and use of experimental animals, and with the ARRIVE guidelines.

Consent to participate

Not applicable

\section{Consent for publication}

Not applicable

Availability of data and material

All the RNA-Seq raw reads were deposited into the Sequencing Read Archive (SRA) of NCBI with the accession number SRR10211853 to SRR10211864. The BioProject ID of our data is PRJNA575250 and the BioSample accession is SAMN12816772.

\section{Acknowledgments}

This study was carried out thanks to the support of the Mexican National Science Council for Science and Technology (CONACYT). The co-author Rigoberto Delgado-Vega also thanks the CONACYT for the scholarship number 262480.

\section{References}

1. Abbink W, Blanco Garcia A, Roques JAC et al (2012) The effect of temperature and pH on the growth and physiological response of juvenile yellowtail kingfish Seriola lalandi in recirculating aquaculture systems. Aquaculture 330-333:130-135. https://doi.org/10.1016/j.aquaculture.2011.11.043

2. Avilés A, Castelló F (2004) Manual para el Cultivo de Seriola lalandi en Baja California sur, México, Jurel. Instituto Nacional de la Pesca, Mexico City 
3. Ottolenghi F, Silvestri C, Giordano P et al (2004) Capture-based aquaculture: the fattening of eels, groupers, tunas and yellowtails. FAO

4. Wolvaardt C (2007) Initiation of Company Coverage IPO

5. Gomon M (2008) Fishes of Australia's southern coast. Reed New Holland, Museum Victoria, Chatswood, N.S.W

6. Nugroho E, Ferrell DJ, Smith P, Taniguchi N (2001) Genetic divergence of kingfish from Japan, Australia and New Zealand inferred by microsatellite DNA and mitochondrial DNA control region markers. Fish Sci 67:843-850. https://doi.org/10.1046/j.1444-2906.2001.00331.x

7. Symonds JE, Walker SP, Pether S et al (2014) Developing yellowtail kingfish (Seriola lalandi) and ha'puku (Polyprion oxygeneios) for New Zealand aquaculture. New Zeal. J Mar Freshw Res 48:371384

8. Riddick EW (2013) Insect Protein as a Partial Replacement for Fishmeal in the Diets of Juvenile Fish and Crustaceans. In: Mass Production of Beneficial Organisms: Invertebrates and Entomopathogens. Elsevier Inc., pp 565-582

9. Kubiriza GK (2018) A review of conventional and unconventional feeds in fish nutrition. Aquac Nutr 24:703-708. https://doi.org/10.3382/ps.0601905

10. Gatlin DM, Barrows FT, Brown P et al (2007) Expanding the utilization of sustainable plant products in aquafeeds: A review. Aquac Res 38:551-579

11. Oliva-Teles A, Enes P, Peres H (2015) Replacing fishmeal and fish oil in industrial aquafeeds for carnivorous fish. In: Feed and Feeding Practices in Aquaculture. Elsevier, pp 203-233

12. Carter CG, Hauler RC (2000) Fish meal replacement by plant meals in extruded feeds for Atlantic salmon. Salmo salar L Aquaculture 185:299-311. https://doi.org/10.1016/S0044-8486(99)00353-1

13. Kader MA, Bulbul M, Koshio $S$ et al (2012) Effect of complete replacement of fishmeal by dehulled soybean meal with crude attractants supplementation in diets for red sea bream, Pagrus major. Aquaculture 350-353:109-116. https://doi.org/10.1016/j.aquaculture.2012.04.009

14. Makkar HPS (1993) Antinutritional factors in foods for livestock. BSAP Occas Publ 16:69-85. https://doi.org/10.1017/s0263967x00031086

15. Francis G, Makkar HPS, Becker K (2001) Antinutritional factors present in plant-derived alternate fish feed ingredients and their effects in fish. Aquaculture 199:197-227

16. Iwashita Y, Yamamoto T, Furuita $\mathrm{H}$ et al (2008) Influence of certain soybean antinutritional factors supplemented to a casein-based semipurified diet on intestinal and liver morphology in fingerling rainbow trout Oncorhynchus mykiss. Fish Sci 74:1075-1082. https://doi.org/10.1111/j.14442906.2008.01627.x

17. Burr G, Hume M, Neill WH, Gatlin DM (2008) Effects of prebiotics on nutrient digestibility of a soybean-meal-based diet by red drum Sciaenops ocellatus (Linnaeus). Aquac Res 39:1680-1686. https://doi.org/10.1111/j.1365-2109.2008.02044.x 
18. Li P, Gatlin DM (2004) Dietary brewers yeast and the prebiotic Grobiotic ${ }^{\mathrm{TM}} A E$ influence growth performance, immune responses and resistance of hybrid striped bass (Morone chrysops $\mathrm{x} M$. saxatilis) to Streptococcus iniae infection. Aquaculture 231:445-456.

https://doi.org/10.1016/j.aquaculture.2003.08.021

19. Li P, Gatlin DM (2005) Evaluation of the prebiotic GroBiotic $®-A$ and brewers yeast as dietary supplements for sub-adult hybrid striped bass (Morone chrysops $\times$ M. saxatilis) challenged in situ with Mycobacterium marinum. In: Aquaculture. Elsevier, pp 197-205

20. Song SK, Beck BR, Kim D et al (2014) Prebiotics as immunostimulants in aquaculture: A review. Fish Shellfish Immunol 40:40-48

21. Gatlin DM (2015) Prebiotics. In: Dietary Nutrients, Additives, and Fish Health. John Wiley \& Sons, Inc, Hoboken, pp 271-281

22. Guerreiro I, Oliva-Teles A, Enes $P$ (2018) Prebiotics as functional ingredients: focus on Mediterranean fish aquaculture. Rev Aquac 10:800-832

23. Manning TS, Gibson GR (2004) Prebiotics. Best Pract. Res Clin Gastroenterol 18:287-298

24. Dalmo RA, Bøgwald J (2008) ß-Glucans As Conductors of Immune Symphonies. Fish Shellfish Immunol 25:384-396

25. Delzenne NM (2003) Oligosaccharides: state of the art. Proc Nutr Soc 62:177-182. https://doi.org/10.1079/PNS2002225

26. Delzenne NM, Williams CM (2002) Prebiotics and lipid metabolism. Curr Opin Lipidol 13:61-67. https://doi.org/10.1097/00041433-200202000-00009

27. Baanante IV, Garcia de Frutos P, Bonamusa L, Fernandez F (1991) Regulation of fish glycolysisgluconeogenesis: role of fructose 2,6 P2 and PFK-2. Comp Biochem Physiol Part B Comp Biochem 100:11-17. https://doi.org/10.1016/0305-0491(91)90077-Q

28. Metón I, Mediavilla D, Caseras A et al (1999) Effect of diet composition and ration size on key enzyme activities of glycolysis-gluconeogenesis, the pentose phosphate pathway and amino acid metabolism in liver of gilthead sea bream (Sparus aurata). Br J Nutr 82:223-232. https://doi.org/10.1017/S0007114599001403

29. Morais S, Pratoomyot J, Taggart JB et al (2011) Genotype-specific responses in Atlantic salmon (Salmo salar) subject to dietary fish oil replacement by vegetable oil: A liver transcriptomic analysis. BMC Genom 12:1-17. https://doi.org/10.1186/1471-2164-12-255

30. Goto T, Takagi S, Ichiki T et al (2001) Studies on the green liver in cultured red sea bream fed low level and non-fish meal diets: Relationship between hepatic taurine and biliverdin levels. Fish Sci 67:58-63. https://doi.org/10.1046/j.1444-2906.2001.00199.x

31. Peng S, Chen L, Qin JG et al (2008) Effects of replacement of dietary fish oil by soybean oil on growth performance and liver biochemical composition in juvenile black seabream, Acanthopagrus schlegeli. Aquaculture 276:154-161. https://doi.org/10.1016/j.aquaculture.2008.01.035

32. Panserat S, Hortopan GA, Plagnes-Juan E et al (2009) Differential gene expression after total replacement of dietary fish meal and fish oil by plant products in rainbow trout (Oncorhynchus 
mykiss) liver. Aquaculture 294:123-131. https://doi.org/10.1016/j.aquaculture.2009.05.013

33. Gille C, Bölling C, Hoppe A et al (2010) HepatoNet1: A comprehensive metabolic reconstruction of the human hepatocyte for the analysis of liver physiology. Mol Syst Biol 6:411.

https://doi.org/10.1038/msb.2010.62

34. Mourente G, Bell JG (2006) Partial replacement of dietary fish oil with blends of vegetable oils (rapeseed, linseed and palm oils) in diets for European sea bass (Dicentrarchus labrax L.) over a long term growth study: Effects on muscle and liver fatty acid composition and effectiv. Comp Biochem Physiol Part B Biochem Mol Biol 145:389-399. https://doi.org/10.1016/j.cbpb.2006.08.012

35. Caballero MJ, López-Calero G, Socorro J et al (1999) Combined effect of lipid level and fish meal quality on liver histology of gilthead seabream (Sparus aurata). Aquaculture 179:277-290. https://doi.org/10.1016/S0044-8486(99)00165-9

36. Tocher DR, Bell JG, MacGlaughlin P et al (2001) Hepatocyte fatty acid desaturation and polyunsaturated fatty acid composition of liver in salmonids: Effects of dietary vegetable oil. Comp Biochem Physiol - B Biochem Mol Biol 130:257-270. https://doi.org/10.1016/S10964959(01)00429-8

37. Liang XF, Ogata HY, Oku H (2002) Effect of dietary fatty acids on lipoprotein lipase gene expression in the liver and visceral adipose tissue of fed and starved red sea bream Pagrus major. In: Comparative Biochemistry and Physiology - A Molecular and Integrative Physiology. Elsevier Inc., pp 913-919

38. Craig SR, Washburn BS, Gatlin DM (1999) Effects of dietary lipids on body composition and liver function in juvenile red drum, Sciaenops ocellatus. Fish Physiol Biochem 21:249-255. https://doi.org/10.1023/A:1007843420128

39. Ruyter B, Moya-Falcón C, Rosenlund G, Vegusdal A (2006) Fat content and morphology of liver and intestine of Atlantic salmon (Salmo salar): Effects of temperature and dietary soybean oil. Aquaculture 252:441-452. https://doi.org/10.1016/j.aquaculture.2005.07.014

40. Farkas T, Csengeri I, Majoros F, Oláh J (1980) Metabolism of fatty acids in fish. III. Combined effect of environmental temperature and diet on formation and deposition of fatty acids in the carp, Cyprinus carpio Linnaeus 1758. Aquaculture 20:29-40. https://doi.org/10.1016/00448486(80)90059-9

41. Sitjà-Bobadilla A, Peña-Llopis S, Gómez-Requeni P et al (2005) Effect of fish meal replacement by plant protein sources on non-specific defence mechanisms and oxidative stress in gilthead sea bream (Sparus aurata). Aquaculture 249:387-400. https://doi.org/10.1016/j.aquaculture.2005.03.031

42. Zheng X, Tocher DR, Dickson CA et al (2004) Effects of diets containing vegetable oil on expression of genes involved in highly unsaturated fatty acid biosynthesis in liver of Atlantic salmon (Salmo salar). Aquaculture 236:467-483. https://doi.org/10.1016/j.aquaculture.2004.02.003

43. Rumsey GL, Kinsella JE, Shetty KJ, Hughes SG (1991) Effect of high dietary concentrations of brewer's dried yeast on growth performance and liver uricase in rainbow trout (Oncorhynchus 
mykiss). Anim Feed Sci Technol 33:177-183. https://doi.org/10.1016/0377-8401(91)90058-Z

44. Chávez-García DS (2016) Efecto del suplemento del prebiótico GroBiotic-A en la dieta sobre el crecimiento, la capacidad digestiva y la respuesta inmune no específica de juveniles de jurel (Seriola lalandi). Centro de Investigación Científica y de Educación Superior de Ensenada, Baja California

45. Jobling M (2003) The thermal growth coefficient (TGC) model of fish growth: A cautionary note. Aquac Res 34:581-584. https://doi.org/10.1046/j.1365-2109.2003.00859.x

46. Bolger AM, Lohse M, Usadel B (2014) Trimmomatic: A flexible trimmer for Illumina sequence data. Bioinformatics 30:2114-2120. https://doi.org/10.1093/bioinformatics/btu170

47. Grabherr MG, Haas BJ, Yassour M et al (2011) Full-length transcriptome assembly from RNA-Seq data without a reference genome. Nat Biotechnol 29:644-652. https://doi.org/10.1038/nbt.1883

48. Langmead B, Salzberg SL (2012) Fast gapped-read alignment with Bowtie 2. Nat Methods 9:357359. https://doi.org/10.1038/nmeth.1923

49. Li B, Dewey CN (2014) RSEM: Accurate transcript quantification from RNA-seq data with or without a reference genome. In: Bioinformatics: The Impact of Accurate Quantification on Proteomic and Genetic Analysis and Research. pp 41-74

50. Love MI, Huber W, Anders S (2014) Moderated estimation of fold change and dispersion for RNA-seq data with DESeq2. Genome Biol 15:1-21. https://doi.org/10.1186/s13059-014-0550-8

51. R Development Core Team (2010) R: A Language and Environment for Statistical Computing. R Foundation for Statistical Computing, Vienna

52. Oliveros JC (2007) VENNY. An interactive tool for comparing lists with Venn Diagrams. http://bioinfogp.cnb.csic.es/tools/venny/index.html. Bioinfogp.Cnb.Csic.Es/Tools/Venny/Index.Html http://bioinfogp.cnnb.csic.es/tools/venny/index.ht

53. Camacho C, Coulouris G, Avagyan V et al (2009) BLAST+: Architecture and applications. BMC Bioinformatics 10:421. https://doi.org/10.1186/1471-2105-10-421

54. Conesa A, Götz S, García-Gómez JM et al (2005) Blast2GO: A universal tool for annotation, visualization and analysis in functional genomics research. Bioinformatics 21:3674-3676. https://doi.org/10.1093/bioinformatics/bti610

55. Huang DW, Sherman BT, Lempicki RA (2009) Systematic and integrative analysis of large gene lists using DAVID bioinformatics resources. Nat Protoc 4:44-57. https://doi.org/10.1038/nprot.2008.211

56. Szklarczyk D, Franceschini A, Wyder S et al (2015) STRING v10: Protein-protein interaction networks, integrated over the tree of life. Nucleic Acids Res 43:D447-D452. https://doi.org/10.1093/nar/gku1003

57. Szklarczyk D, Morris JH, Cook H et al (2017) The STRING database in 2017: Quality-controlled protein-protein association networks, made broadly accessible. Nucleic Acids Res 45:D362-D368. https://doi.org/10.1093/nar/gkw937

58. Lee J, Choi J, Selen Alpergin ES et al (2017) Loss of Hepatic Mitochondrial Long-Chain Fatty Acid Oxidation Confers Resistance to Diet-Induced Obesity and Glucose Intolerance. Cell Rep 20:655-667. 
https://doi.org/10.1016/j.celrep.2017.06.080

59. Nguyen P, Leray V, Diez M et al (2008) Liver lipid metabolism. J Anim Physiol Anim Nutr (Berl) 92:272-283. https://doi.org/10.1111/j.1439-0396.2007.00752.x

60. Bowyer JN, Qin JG, Smullen RP et al (2013) The use of a soy product in juvenile yellowtail kingfish (Seriola lalandi) feeds at different water temperatures: 2. Soy protein concentrate. Aquaculture 410411:1-10. https://doi.org/10.1016/j.aquaculture.2013.06.001

61. Bowyer JN, Qin JG, Smullen RP et al (2013) The use of a soy product in juvenile yellowtail kingfish (Seriola lalandi) feeds at different water temperatures: 1. Solvent extracted soybean meal. Aquaculture 384-387:35-45. https://doi.org/10.1016/j.aquaculture.2012.12.005

62. Jirsa D, Davis A, Stuart K, Drawbridge M (2011) Development of a practical soy-based diet for California yellowtail, Seriola lalandi. Aquac Nutr 17:e869-e874. https://doi.org/10.1111/j.13652095.2011.00856.x

63. Stone DAJ, Bellgrove EJ, Forder REA et al (2018) Inducing Subacute Enteritis in Yellowtail Kingfish Seriola lalandi: the Effect of Dietary Inclusion of Soybean Meal and Grape Seed Extract on Hindgut Morphology and Inflammation. N Am J Aquac 80:59-68. https://doi.org/10.1002/naaq.10002

64. Guerra-Olvera FM, Viana MT (2015) Efecto del contenido de colesterol en las dietas y su acumulación en hígado y músculo en juveniles de jurel de Castilla (Seriola lalandi). Ciencias Mar 41:143-156. https://doi.org/10.7773/cm.v41i2.2514

65. Rasal KD, Shah TM, Vaidya M et al (2015) Analysis of consequences of non-synonymous SNP in feed conversion ratio associated TGF- $\beta$ receptor type 3 gene in chicken. Meta Gene 4:107-117. https://doi.org/10.1016/j.mgene.2015.03.006

66. Gahr SA, Weber GM, Rexroad CE (2012) Identification and expression of Smads associated with TGF$\beta /$ activin/nodal signaling pathways in the rainbow trout (Oncorhynchus mykiss). Fish Physiol Biochem 38:1233-1244. https://doi.org/10.1007/s10695-012-9611-7

67. Yoshida GM, Lhorente JP, Carvalheiro R, Yáñez JM (2017) Bayesian genome-wide association analysis for body weight in farmed Atlantic salmon (Salmo salar L.). Anim Genet 48:698-703. https://doi.org/10.1111/age.12621

68. Du J, Chen X, Wang J et al (2019) Comparative skin transcriptome of two Oujiang color common carp (Cyprinus carpio var. color) varieties. Fish Physiol Biochem 45:177-185. https://doi.org/10.1007/s10695-018-0551-8

69. Seiliez I, Gabillard JC, Skiba-Cassy S et al (2008) An in vivo and in vitro assessment of TOR signaling cascade in rainbow trout (Oncorhynchus mykiss). Am J Physiol - Regul Integr Comp Physiol 295:329-335. https://doi.org/10.1152/ajpregu.00146.2008

70. Muirhead H, Watson H (1992) Glycolytic enzymes: from hexose to pyruvate. Curr Opin Struct Biol 2:870-876. https://doi.org/10.1016/0959-440X(92)90113-L

71. Wu C, Okar DA, Newgard CB, Lange AJ (2001) Overexpression of 6-phosphofructo-2-kinase/fructose2,6-bisphosphatase in mouse liver lowers blood glucose by suppressing hepatic glucose production. J Clin Invest 107:91-98. https://doi.org/10.1172/JCl11103 
72. Metón I, Caseras A, Fernández F, Baanante IV (2000) 6-Phosphofructo-2-kinase/fructose-2,6bisphosphatase gene expression is regulated by diet composition and ration size in liver of gilthead sea bream, Sparus aurata. Biochim Biophys Acta - Gene Struct Expr 1491:220-228. https://doi.org/10.1016/S0167-4781(00)00040-3

73. Clarke JL, Mason PJ (2003) Murine hexose-6-phosphate dehydrogenase: A bifunctional enzyme with broad substrate specificity and 6-phosphogluconolactonase activity. Arch Biochem Biophys 415:229-234. https://doi.org/10.1016/S0003-9861(03)00229-7

74. Kotaka M, Gover S, Vandeputte-Rutten L et al (2005) Structural studies of glucose-6-phosphate and NADP + binding to human glucose-6-phosphate dehydrogenase. Acta Crystallogr Sect D Biol Crystallogr 61:495-504. https://doi.org/10.1107/S0907444905002350

75. Printen JA, Brady MJ, Saltiel AR (1997) PTG, a protein phosphate 1-binding protein with a role in glycogen metabolism. Science 275:1475-1478. https://doi.org/10.1126/science.275.5305.1475

76. Urs S, Smith C, Campbell B et al (2004) Gene Expression Profiling in Human Preadipocytes and Adipocytes by Microarray Analysis. J Nutr 134:762-770. https://doi.org/10.1093/jn/134.4.762

77. Onat OE, Gulsuner S, Bilguvar K et al (2013) Missense mutation in the ATPase, aminophospholipid transporter protein ATP8A2 is associated with cerebellar atrophy and quadrupedal locomotion. Eur $\mathrm{J}$ Hum Genet 21:281-285. https://doi.org/10.1038/ejhg.2012.170

78. Jaye M, Lynch KJ, Krawiec J et al (1999) A novel endothelial-derived lipase that modulates HDL metabolism. Nat Genet 21:424-428. https://doi.org/10.1038/7766

79. Gropler MC, Harris TE, Hall AM et al (2009) Lipin 2 is a liver-enriched phosphatidate phosphohydrolase enzyme that is dynamically regulated by fasting and obesity in mice. J Biol Chem 284:6763-6772. https://doi.org/10.1074/jbc.M807882200

80. Leduc A, Zatylny-Gaudin C, Robert M et al (2018) Dietary aquaculture by-product hydrolysates: Impact on the transcriptomic response of the intestinal mucosa of European seabass (Dicentrarchus labrax) fed low fish meal diets. BMC Genom 19:396. https://doi.org/10.1186/s12864-018-4780-0

81. Saurabh S, Sahoo PK (2008) Lysozyme: An important defence molecule of fish innate immune system. Aquac Res 39:223-239

82. Tedder TF, Tuscano J, Sato S, Kehrl JH (1997) CD22, A B lymphocyte-specific adhesion molecule that regulates antigen receptor signaling. Annu Rev Immunol 15:481-504. https://doi.org/10.1146/annurev.immunol.15.1.481

83. Nitschke L (2009) CD22 and Siglec-G: B-cell inhibitory receptors with distinct functions. Immunol Rev 230:128-143

84. Yang Y, Yu H, Li H, Wang A (2016) Transcriptome profiling of grass carp (Ctenopharyngodon idellus) infected with Aeromonas hydrophila. Fish Shellfish Immunol 51:329-336. https://doi.org/10.1016/j.fsi.2016.02.035

85. Feng J, De Jesus PD, Su V et al (2014) RIOK3 Is an Adaptor Protein Required for IRF3-Mediated Antiviral Type I Interferon Production. J Virol 88:7987-7997. https://doi.org/10.1128/jvi.00643-14 
86. Cerezuela R, Meseguer J, Esteban M (2013) Effects of dietary inulin, Bacillus subtilis and microalgae on intestinal gene expression in gilthead seabream (Sparus aurata L.). Fish Shellfish Immunol 34:843-848. https://doi.org/10.1016/j.fsi.2012.12.026

87. Dudkina NV, Spicer BA, Reboul CF et al (2016) Structure of the poly-C9 component of the complement membrane attack complex. Nat Commun 7:1-6. https://doi.org/10.1038/ncomms10588

88. Fu YW, Zhu CK, Zhang QZ, Hou TL (2019) Molecular characterization, expression analysis, and ontogeny of complement component $\mathrm{C} 9$ in southern catfish (Silurus meridionalis). Fish Shellfish Immunol 86:449-458. https://doi.org/10.1016/j.fsi.2018.11.069

89. Guo B, Wu C, Lv Z, Liu C (2016) Characterisation and expression analysis of two terminal complement components: C7 and C9 from large yellow croaker, Larimichthys crocea. Fish Shellfish Immunol 51:211-219. https://doi.org/10.1016/j.fsi.2016.01.015

90. Alper CA, Abramson N, Johnston RB et al (1970) Studies in vivo and in vitro on an abnormality in the metabolism of $C 3$ in a patient with increased susceptibility to infection. J Clin Invest 49:1975-1985. https://doi.org/10.1172/JCl106417

91. Maslowska M, Vu H, Phelis S et al (1999) Plasma acylation stimulating protein, adipsin and lipids in non-obese and obese populations. Eur J Clin Invest 29:679-686. https://doi.org/10.1046/j.13652362.1999.00514.x

92. Koistinen HA, Vidal H, Karonen SL et al (2001) Plasma acylation stimulating protein concentration and subcutaneous adipose tissue C3 mRNA expression in nondiabetic and type 2 diabetic men. Arterioscler Thromb Vasc Biol 21:1034-1039. https://doi.org/10.1161/01.ATV.21.6.1034

\section{Tables}

Table 1. Proximal composition and formulation of experimental diets. 


\begin{tabular}{|lllll|}
\hline Proximal composition & FM & FM-P & SM25 & SM25-P \\
\hline Proteins & $45.4 \pm 1.2$ & $47.0 \pm 0.5$ & $48.8 \pm 0.5$ & $49.6 \pm 0.5$ \\
\hline Lipids & $18.6 \pm 0.4$ & $19.5 \pm 0.3$ & $20.1 \pm 0.3$ & $21.2 \pm 0.6$ \\
\hline Humidity & $0.3 \pm 0.02$ & $0.6 \pm 0.05$ & $0.7 \pm 0.02$ & $2.0 \pm 0.07$ \\
\hline Ashes & $13.2 \pm 0.10$ & $13.2 \pm 0.19$ & $12.9 \pm 0.13$ & $13.0 \pm 0.07$ \\
\hline Ingredients & & & & \\
\hline Soybean meal & 0 & 0 & 15 & 15 \\
\hline Chicken meal & 9 & 9 & 9 & 9 \\
\hline Fish meal & 55 & 55 & 45 & 45 \\
\hline Fish Oil & 11.3 & 11.9 & 13 & 13 \\
\hline Starch & 14 & 11.4 & 5.3 & 3.3 \\
\hline Jelly & 2 & 2 & 2 & 2 \\
\hline Rovimix & 5 & 5 & 5 & 5 \\
\hline Stay C & 1.5 & 1.5 & 1.5 & 1.5 \\
\hline Lecithin & 1 & 1 & 1 & 1 \\
\hline Taurine & 1 & 1 & 3 & 3 \\
\hline Sodium benzoate & 0.2 & 0.2 & 0.2 & 0.2 \\
\hline GroBiotic $®-A$ & 0 & 2 & 0 & 2 \\
\hline BHT & 0.01 & 0.01 & 0.01 & 0.01 \\
\hline
\end{tabular}

$\mathrm{FM}=$ fish meal as main protein source, FM-P $=\mathrm{FM}$ with $2 \%$ prebiotic, SM25-P $=25 \% \mathrm{FM}$ replacement by soybean meal and $2 \%$ prebiotic, SM $25=25 \%$ FM replacement by soybean meal. The values of ingredients are expressed in percentages. Taken and modified from [44].

Table 2. Growth results for each treatment. 


\begin{tabular}{|llllllll|}
\hline & FM & FM-P & SM25 & SM25-P & M & P & MxP \\
\hline Initial weight (g) & $97.5 \pm 3.5$ & $96.0 \pm 1.5$ & $99.6 \pm 1.3$ & $98.5 \pm 0.8$ & NS & NS & NS \\
\hline Gained weight (g) & $124.9 \pm 18.5$ & $161.4 \pm 33.6$ & $140.2 \pm 6.4$ & $165.6 \pm 10.7$ & NS & $* \star \star$ & NS \\
\hline Gained weight (\%) & $127.9 \pm 15.9$ & $167.9 \pm 32.3$ & $140.7 \pm 4.7$ & $168.1 \pm 9.4$ & NS & $* \star \star$ & NS \\
\hline TGC & $1.11 \pm 0.10$ & $1.35 \pm 0.18$ & $1.20 \pm 0.02$ & $1.36 \pm 0.09$ & NS & $* \star *$ & NS \\
\hline FCR & $1.53 \pm 0.12$ & $1.36 \pm 0.13$ & $1.49 \pm 0.08$ & $1.33 \pm 0.02$ & NS & $* \star *$ & NS \\
\hline
\end{tabular}

$\mathrm{FM}=$ fish meal as main protein source, FM-P $=\mathrm{FM}$ with $2 \%$ prebiotic, SM25-P $=25 \% \mathrm{FM}$ replacement by soybean meal and $2 \%$ prebiotic, SM25 $=25 \% \mathrm{FM}$ replacement by soybean meal. TGC $=$ Thermal growth coefficient. $F C R=$ feed conversion rate. $M=$ Meal. $P=$ Prebiotic. $N S=$ no significant difference. ${ }^{\star \star \star}=\mathrm{P}<$ 0.05. Taken and modified from [44].

Table 3. Selected differentially expressed genes for cluster analysis. 


\begin{tabular}{|c|c|c|c|c|}
\hline Transcript & BLASTx hit & Process & Gene & Protein name \\
\hline TRINITY_DN27611_c4_g1_i9 & KCC2G_HUMAN & C & CAMK2G & $\begin{array}{l}\text { Calcium/calmodulin- } \\
\text { dependent protein } \\
\text { kinase type Il subunit } \\
\text { gamma }\end{array}$ \\
\hline TRINITY_DN26269_c2_g1_i2 & ENOB_SALSA & $\mathrm{C}$ & ENO3 & Beta-enolase \\
\hline TRINITY_DN27760_c1_g2_i11 & G6PD_TAKRU & $\mathrm{C}$ & G6PD & $\begin{array}{l}\text { Glucose-6-phosphate 1- } \\
\text { dehydrogenase }\end{array}$ \\
\hline TRINITY_DN28668_c0_g1_i5 & G6PE_MOUSE & $\mathrm{C}$ & H6PD & $\begin{array}{l}\text { GDH/6PGL } \\
\text { endoplasmic } \\
\text { bifunctional protein }\end{array}$ \\
\hline TRINITY_DN28824_C0_g1_i10 & F264_HUMAN & C & PFKFB4 & $\begin{array}{l}\text { 6-phosphofructo-2- } \\
\text { kinase/fructose-2,6- } \\
\text { bisphosphatase } 4\end{array}$ \\
\hline TRINITY_DN27130_c1_g1_i3 & PR3CB_DANRE & C & ppp1r3cb & $\begin{array}{l}\text { Protein phosphatase } 1 \\
\text { regulatory subunit } 3 \mathrm{C}-\mathrm{B}\end{array}$ \\
\hline TRINITY_DN29572_c3_g1_i23 & SRBS1_HUMAN & C & SORBS1 & $\begin{array}{l}\text { Sorbin and } \mathrm{SH} 3 \\
\text { domain-containing } \\
\text { protein } 1\end{array}$ \\
\hline TRINITY_DN26067_c0_g1_i1 & EPS8_MOUSE & G & EPS8 & $\begin{array}{l}\text { Epidermal growth } \\
\text { factor receptor kinase } \\
\text { substrate } 8\end{array}$ \\
\hline TRINITY_DN23956_c0_g1_i2 & MTOR_MOUSE & G & MTOR & $\begin{array}{l}\text { Serine/threonine- } \\
\text { protein kinase mTOR }\end{array}$ \\
\hline TRINITY_DN26179_c0_g1_i18 & RPTOR_HUMAN & G & RPTOR & $\begin{array}{l}\text { Regulatory-associated } \\
\text { protein of mTOR }\end{array}$ \\
\hline TRINITY_DN25891_c0_g1_i2 & SCUB3_MOUSE & G & SCUBE3 & $\begin{array}{l}\text { Signal peptide, CUB } \\
\text { and EGF-like domain- } \\
\text { containing protein } 3\end{array}$ \\
\hline TRINITY_DN30106_c1_g2_i10 & SMAD4_RAT & G & SMAD4 & $\begin{array}{l}\text { Mothers against } \\
\text { decapentaplegic } \\
\text { homolog } 4\end{array}$ \\
\hline TRINITY_DN18300_c0_g1_i2 & TGBR3_MOUSE & G & TGFBR3 & $\begin{array}{l}\text { Transforming growth } \\
\text { factor-beta receptor } \\
\text { type } 3\end{array}$ \\
\hline TRINITY_DN22340_c0_g1_i1 & ZFN2B_HUMAN & G & ZFAND2B & $\begin{array}{l}\text { AN1-type zinc finger } \\
\text { protein } 2 B\end{array}$ \\
\hline TRINITY_DN26104_c0_g1_i2 & C1QB_MOUSE & 1 & $\mathrm{C} 1 \mathrm{qb}$ & $\begin{array}{l}\text { Complement C1q } \\
\text { subcomponent subunit } \\
\text { B }\end{array}$ \\
\hline TRINITY_DN27901_c1_g2_i11 & CO9_TAKRU & 1 & C9 & $\begin{array}{l}\text { Complement } \\
\text { component C9 }\end{array}$ \\
\hline
\end{tabular}




\begin{tabular}{|c|c|c|c|c|}
\hline TRINITY_DN23812_c0_g1_i1 & CASP1_PIG & 1 & CASP1 & Caspase-1 \\
\hline TRINITY_DN30179_c2_g2_i13 & CD22_HUMAN & I & CD22 & B-cell receptor CD22 \\
\hline TRINITY_DN29613_c2_g1_i6 & MY18A_HUMAN & 1 & MY018A & $\begin{array}{l}\text { Unconventional } \\
\text { myosin-XVIIla }\end{array}$ \\
\hline TRINITY_DN27406_c2_g1_i5 & NOTC2_HUMAN & 1 & NOTCH2 & $\begin{array}{l}\text { Neurogenic locus notch } \\
\text { homolog protein } 2\end{array}$ \\
\hline TRINITY_DN29910_c2_g2_i6 & P85A_HUMAN & 1 & P85A & $\begin{array}{l}\text { Phosphatidylinositol 3- } \\
\text { kinase regulatory } \\
\text { subunit alpha }\end{array}$ \\
\hline TRINITY_DN25444_c0_g1_i5 & RIOK3_HUMAN & 1 & RIOK3 & $\begin{array}{l}\text { Serine/threonine- } \\
\text { protein kinase RIO3 }\end{array}$ \\
\hline TRINITY_DN27700_c0_g1_i6 & TCAIM_HUMAN & 1 & TCAIM & $\begin{array}{l}\text { T-cell activation } \\
\text { inhibitor, mitochondrial }\end{array}$ \\
\hline TRINITY_DN18468_c0_g1_i4 & TRAF3_MOUSE & 1 & TRAF3 & $\begin{array}{l}\text { TNF receptor- } \\
\text { associated factor } 3\end{array}$ \\
\hline TRINITY_DN29039_c3_g2_i1 & ABH2A_DANRE & $\mathrm{L}$ & abhd2a & $\begin{array}{l}\text { Monoacylglycerol } \\
\text { lipase ABHD2 }\end{array}$ \\
\hline TRINITY_DN26059_c0_g1_i2 & ACSF3_MOUSE & $\mathrm{L}$ & ACSF3 & $\begin{array}{l}\text { Acyl-CoA synthetase } \\
\text { family member } 3\end{array}$ \\
\hline TRINITY_DN27331_c0_g1_i10 & ANGL3_MOUSE & $\mathrm{L}$ & ANGPTL3 & $\begin{array}{l}\text { Angiopoietin-related } \\
\text { protein } 3\end{array}$ \\
\hline TRINITY_DN26503_c1_g1_i3 & AT8A2_MOUSE & $\mathrm{L}$ & ATP8A2 & $\begin{array}{l}\text { Phospholipid- } \\
\text { transporting ATPase IB }\end{array}$ \\
\hline TRINITY_DN28443_c0_g1_i16 & LIPE_HUMAN & $\mathrm{L}$ & LIPG & Endothelial lipase \\
\hline TRINITY_DN27990_c1_g1_i12 & LPIN2_MOUSE & $\mathrm{L}$ & LPIN2 & $\begin{array}{l}\text { Phosphatidate } \\
\text { phosphatase LPIN2 }\end{array}$ \\
\hline TRINITY_DN29764_c0_g2_i4 & LRP5_HUMAN & L & LRP5 & $\begin{array}{l}\text { Low-density lipoprotein } \\
\text { receptor-related protein } \\
5\end{array}$ \\
\hline TRINITY_DN29140_c3_g3_i2 & LSR_MOUSE & L & LSR & $\begin{array}{l}\text { Lipolysis-stimulated } \\
\text { lipoprotein receptor }\end{array}$ \\
\hline TRINITY_DN29650_c0_g1_i4 & NF2L1_HUMAN & $\mathrm{L}$ & NFE2L1 & $\begin{array}{l}\text { Endoplasmic reticulum } \\
\text { membrane sensor } \\
\text { NFE2L1 }\end{array}$ \\
\hline TRINITY_DN23944_c1_g1_i1 & STAR3_DANRE & $\mathrm{L}$ & STARD3 & $\begin{array}{l}\text { StAR-related lipid } \\
\text { transfer protein } 3\end{array}$ \\
\hline
\end{tabular}

$\mathrm{G}=$ Growth, $\mathrm{L}=$ lipid metabolism, $\mathrm{C}=$ carbohydrate metabolism/homeostasis, I = immune system.

Table 4. Top 20 enriched biological processes for the reference liver transcriptome of $S$. lalandi juveniles 


\begin{tabular}{|c|c|c|c|c|}
\hline GO & Term & Count & P-Value & $\begin{array}{l}\text { Fold } \\
\text { Enrichment }\end{array}$ \\
\hline G0:0030030 & cell projection organization & 33 & $\begin{array}{l}7.12 \mathrm{E}- \\
21\end{array}$ & 6.362 \\
\hline GO:0007093 & mitotic cell cycle checkpoint & 8 & $\begin{array}{l}6.68 \mathrm{E}- \\
05\end{array}$ & 6.169 \\
\hline GO:0008380 & RNA splicing & 42 & $\begin{array}{l}1.95 \mathrm{E}- \\
23\end{array}$ & 5.655 \\
\hline GO:0000266 & mitochondrial fission & 10 & $\begin{array}{l}1.10 \mathrm{E}- \\
05\end{array}$ & 5.655 \\
\hline GO:0051028 & mRNA transport & 17 & $\begin{array}{l}2.16 \mathrm{E}- \\
09\end{array}$ & 5.546 \\
\hline GO:0016569 & covalent chromatin modification & 54 & $\begin{array}{l}6.37 \mathrm{E}- \\
29\end{array}$ & 5.453 \\
\hline GO:0007067 & mitotic nuclear division & 48 & $\begin{array}{l}1.53 \mathrm{E}- \\
23\end{array}$ & 5.027 \\
\hline GO:0006974 & cellular response to DNA damage stimulus & 64 & $\begin{array}{l}2.41 \mathrm{E}- \\
30\end{array}$ & 4.891 \\
\hline GO:0006397 & mRNA processing & 63 & $\begin{array}{l}1.19 \mathrm{E}- \\
29\end{array}$ & 4.858 \\
\hline GO:0006446 & regulation of translational initiation & 12 & $\begin{array}{l}6.72 \mathrm{E}- \\
06\end{array}$ & 4.847 \\
\hline GO:0001731 & $\begin{array}{l}\text { formation of translation preinitiation } \\
\text { complex }\end{array}$ & 13 & $\begin{array}{l}2.67 \mathrm{E}- \\
06\end{array}$ & 4.794 \\
\hline GO:0031047 & gene silencing by RNA & 14 & $\begin{array}{l}1.07 \mathrm{E}- \\
06\end{array}$ & 4.750 \\
\hline GO:0007049 & cell cycle & 89 & $\begin{array}{l}7.44 \mathrm{E}- \\
40\end{array}$ & 4.660 \\
\hline GO:0008654 & phospholipid biosynthetic process & 14 & $\begin{array}{l}1.90 \mathrm{E}- \\
06\end{array}$ & 4.567 \\
\hline GO:0051301 & cell division & 57 & $\begin{array}{l}5.35 \mathrm{E}- \\
25\end{array}$ & 4.561 \\
\hline GO:0008202 & steroid metabolic process & 12 & $\begin{array}{l}2.06 \mathrm{E}- \\
05\end{array}$ & 4.426 \\
\hline GO:0006417 & regulation of translation & 20 & $\begin{array}{l}3.85 \mathrm{E}- \\
08\end{array}$ & 4.138 \\
\hline GO:0008045 & motor neuron axon guidance & 16 & $\begin{array}{l}2.29 \mathrm{E}- \\
06\end{array}$ & 3.992 \\
\hline GO:0015031 & protein transport & 91 & $1.12 \mathrm{E}-$ & 3.979 \\
\hline
\end{tabular}


GO:0002376 immune system process

16

$1.21 \mathrm{E}-\quad 3.572$

05

Table 5. Top 20 enriched KEGG pathways for the reference liver transcriptome of $\boldsymbol{S}$. lalandi juveniles

\begin{tabular}{|lllll|}
\hline KEGG pathway & Term & Count & P-Value & Fold Enrichment \\
\hline hsa00500 & Starch and sucrose metabolism & 20 & 0.001656 & 1.927 \\
\hline hsa02010 & ABC transporters & 26 & $4.20 \mathrm{E}-04$ & 1.878 \\
\hline hsa04070 & Phosphatidylinositol signaling system & 57 & $1.08 \mathrm{E}-07$ & 1.849 \\
\hline hsa00562 & Inositol phosphate metabolism & 41 & $1.13 \mathrm{E}-05$ & 1.836 \\
\hline hsa04520 & Adherens junction & 40 & $3.22 \mathrm{E}-05$ & 1.791 \\
\hline hsa04666 & Fc gamma R-mediated phagocytosis & 46 & $1.92 \mathrm{E}-05$ & 1.741 \\
\hline hsa04925 & Aldosterone synthesis and secretion & 42 & $2.35 \mathrm{E}-04$ & 1.648 \\
\hline hsa04150 & mTOR signaling pathway & 30 & 0.002368 & 1.644 \\
\hline hsa05220 & Chronic myeloid leukemia & 37 & $7.45 \mathrm{E}-04$ & 1.634 \\
\hline hsa05100 & Bacterial invasion of epithelial cells & 40 & $4.56 \mathrm{E}-04$ & 1.630 \\
\hline hsa04360 & Axon guidance & 64 & $1.28 \mathrm{E}-05$ & 1.602 \\
\hline hsa04911 & Insulin secretion & 42 & $8.42 \mathrm{E}-04$ & 1.571 \\
\hline hsa04662 & B cell receptor signaling pathway & 34 & 0.003109 & 1.566 \\
\hline hsa04611 & Platelet activation & 64 & $3.25 \mathrm{E}-05$ & 1.565 \\
\hline hsa04919 & Thyroid hormone signaling pathway & 55 & $3.24 \mathrm{E}-04$ & 1.520 \\
\hline hsa05231 & Choline metabolism in cancer & 48 & $9.85 \mathrm{E}-04$ & 1.511 \\
\hline hsa04015 & Rap1 signaling pathway & 99 & $2.01 \mathrm{E}-06$ & 1.499 \\
\hline hsa04931 & Insulin resistance & 50 & 0.001542 & 1.472 \\
\hline hsa04922 & Glucagon signaling pathway & 45 & 0.004222 & 1.445 \\
\hline hsa04910 & Insulin signaling pathway & 62 & $9.96 \mathrm{E}-04$ & 1.428 \\
\hline
\end{tabular}

Table 6. Enriched biological processes in each treatment vs the control diet (Fisher exact test). 


\begin{tabular}{|c|c|c|c|}
\hline Up-regulated genes & P-Value & Down-regulated genes & P-Value \\
\hline \multicolumn{4}{|l|}{ FM-P } \\
\hline $\begin{array}{l}\text { Negative regulation of I-kappaB } \\
\text { kinase/NF-kappaB signaling }\end{array}$ & 0.00009 & tRNA modification & 0.00080 \\
\hline $\begin{array}{l}\text { Cellular response to leukemia } \\
\text { inhibitory factor }\end{array}$ & 0.00027 & RNA splicing & 0.03796 \\
\hline $\begin{array}{l}\text { Negative regulation of protein } \\
\text { catabolic process }\end{array}$ & 0.00046 & Endoplasmic reticulum organization & 0.03893 \\
\hline Actin filament bundle assembly & 0.00200 & $\begin{array}{l}\text { Negative regulation of actin filament } \\
\text { polymerization }\end{array}$ & 0.03958 \\
\hline Regulation of cell shape & 0.00272 & $\begin{array}{l}\text { Intrinsic apoptotic signaling pathway } \\
\text { in response to DNA damage }\end{array}$ & 0.04045 \\
\hline Negative regulation of cell migration & 0.00318 & Myeloid cell development & 0.04239 \\
\hline Actomyosin structure organization & 0.00362 & Cell aging & 0.04282 \\
\hline $\begin{array}{l}\text { Protein localization to plasma } \\
\text { membrane }\end{array}$ & 0.00832 & $\begin{array}{l}\text { Positive regulation of canonical Wnt } \\
\text { signaling pathway }\end{array}$ & 0.04434 \\
\hline \multirow[t]{2}{*}{ Glucose metabolic process } & 0.03426 & Cholesterol transport & 0.04628 \\
\hline & & Cytoplasmic translation & 0.04778 \\
\hline \multicolumn{4}{|l|}{ SM25-P } \\
\hline Tyrosine catabolic process & 0.00006 & Cholesterol homeostasis & 0.00000 \\
\hline L-phenylalanine catabolic process & 0.00012 & $\begin{array}{l}\text { Positive regulation of high-density } \\
\text { lipoprotein particle clearance }\end{array}$ & 0.00000 \\
\hline $\begin{array}{l}\text { Retrograde transport, endosome to } \\
\text { Golgi }\end{array}$ & 0.00106 & $\begin{array}{l}\text { High-density lipoprotein particle } \\
\text { remodeling }\end{array}$ & 0.00001 \\
\hline $\begin{array}{l}\text { Negative regulation of apoptotic } \\
\text { process }\end{array}$ & 0.00296 & Phospholipid homeostasis & 0.00002 \\
\hline $\begin{array}{l}\text { Positive regulation of NF-kappaB } \\
\text { transcription factor activity }\end{array}$ & 0.04573 & Reverse cholesterol transport & 0.00002 \\
\hline Lysosomal transport & 0.04757 & $\begin{array}{l}\text { Positive regulation of cholesterol } \\
\text { transport }\end{array}$ & 0.00003 \\
\hline $\begin{array}{l}\text { Cellular response to } \\
\text { lipopolysaccharide }\end{array}$ & 0.04794 & Phospholipid catabolic process & 0.00006 \\
\hline \multirow[t]{3}{*}{ Fatty acid biosynthetic process } & 0.04886 & Regulation of cell shape & 0.04537 \\
\hline & & Muscle contraction & 0.04571 \\
\hline & & Canonical Wnt signaling pathway & 0.04942 \\
\hline
\end{tabular}




\begin{tabular}{|c|c|c|c|}
\hline Gene silencing & 0.02245 & $\begin{array}{l}\text { Regulation of transcription by RNA } \\
\text { polymerase II }\end{array}$ & 0.00438 \\
\hline Cell junction organization & 0.03829 & $\begin{array}{l}\text { Positive regulation of transcription, } \\
\text { DNA-templated }\end{array}$ & 0.00717 \\
\hline Response to bacterium & 0.04536 & $\begin{array}{l}\text { Protein modification by small protein } \\
\text { conjugation or removal }\end{array}$ & 0.02074 \\
\hline Cilium assembly & 0.04660 & Positive regulation of cell migration & 0.02816 \\
\hline $\begin{array}{l}\text { Negative regulation of protein } \\
\text { phosphorylation }\end{array}$ & 0.04821 & Cell division & 0.04160 \\
\hline \multirow[t]{5}{*}{ Protein dephosphorylation } & 0.04839 & $\begin{array}{l}\text { Cellular response to cytokine } \\
\text { stimulus }\end{array}$ & 0.04280 \\
\hline & & Pathogenesis & 0.04649 \\
\hline & & $\begin{array}{l}\text { Positive regulation of protein kinase } \\
\text { B signaling }\end{array}$ & 0.04714 \\
\hline & & $\begin{array}{l}\text { Vascular endothelial growth factor } \\
\text { receptor signaling pathway }\end{array}$ & 0.04886 \\
\hline & & Regulation of stress fiber assembly & 0.04972 \\
\hline
\end{tabular}

Table 7. Enriched metabolic pathways in treatments versus the control diet. 


\begin{tabular}{|c|c|c|c|c|}
\hline FM-P Up-regulated & $\begin{array}{l}\text { P- } \\
\text { Value }\end{array}$ & $\begin{array}{l}\text { Fold } \\
\text { Enrichment }\end{array}$ & Genes & Protein name \\
\hline \multirow[t]{5}{*}{ Metabolic pathways } & 0.019 & 4.55 & METK2 & S-adenosylmethionine synthase 2 \\
\hline & & & HUTU & Urocanate hydratase \\
\hline & & & G6PE & $\begin{array}{l}\text { GDH/6PGL endoplasmic } \\
\text { bifunctional protein }\end{array}$ \\
\hline & & & PI4KA & $\begin{array}{l}\text { Phosphatidylinositol 4-kinase } \\
\text { alpha }\end{array}$ \\
\hline & & & LPIN2 & Phosphatidate phosphatase \\
\hline \multirow[t]{2}{*}{$\begin{array}{l}\text { Synaptic Proteins at the } \\
\text { Synaptic Junction }\end{array}$} & 0.047 & 32.83 & ANK1 & Ankyrin-1 \\
\hline & & & EPB41 & Protein 4.1 \\
\hline \multicolumn{5}{|l|}{ FM-P Down-regulated } \\
\hline \multirow[t]{3}{*}{ Metabolic pathways } & 0.034 & 8.53 & CD38 & $\begin{array}{l}\text { ADP-ribosyl cyclase/cyclic ADP- } \\
\text { ribose hydrolase } 1\end{array}$ \\
\hline & & & PNPH & Purine nucleoside phosphorylase \\
\hline & & & PCY1B & $\begin{array}{l}\text { Choline-phosphate } \\
\text { cytidylyltransferase B }\end{array}$ \\
\hline \multicolumn{5}{|l|}{ SM25 Down-regulated } \\
\hline \multirow[t]{2}{*}{$\begin{array}{l}\text { Rac } 1 \text { cell motility signaling } \\
\text { pathway }\end{array}$} & 0.024 & 54.72 & MYLK & $\begin{array}{l}\text { Myosin light chain kinase, } \\
\text { smooth muscle }\end{array}$ \\
\hline & & & P85A & $\begin{array}{l}\text { Phosphatidylinositol 3-kinase } \\
\text { regulatory subunit alpha }\end{array}$ \\
\hline
\end{tabular}

\section{Figures}


FM-P

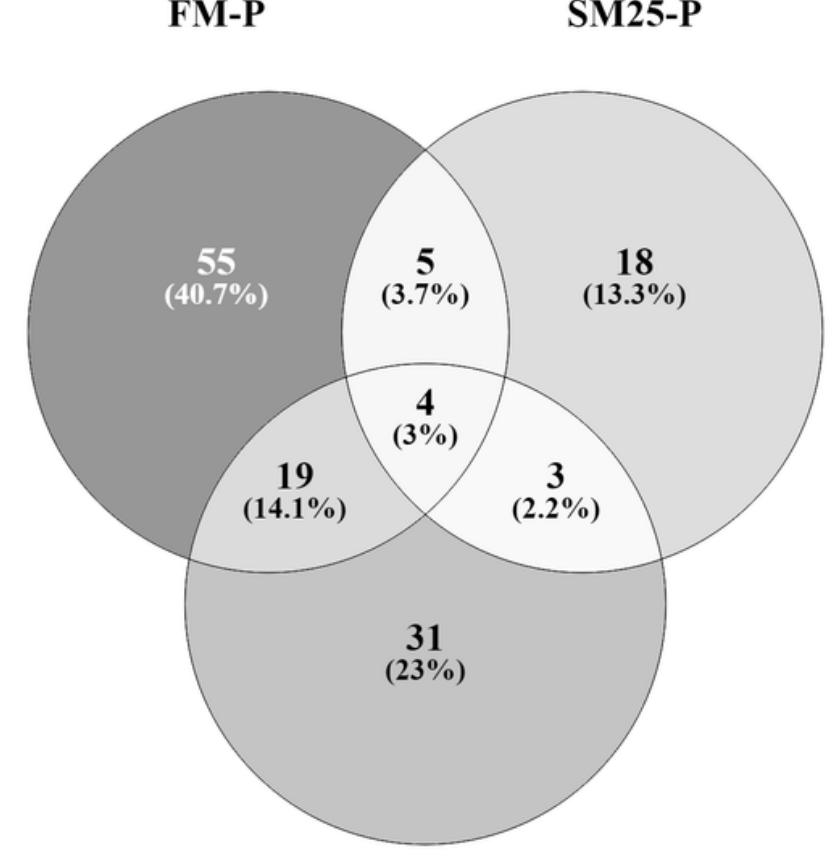

SM25
FM-P

SM25-P

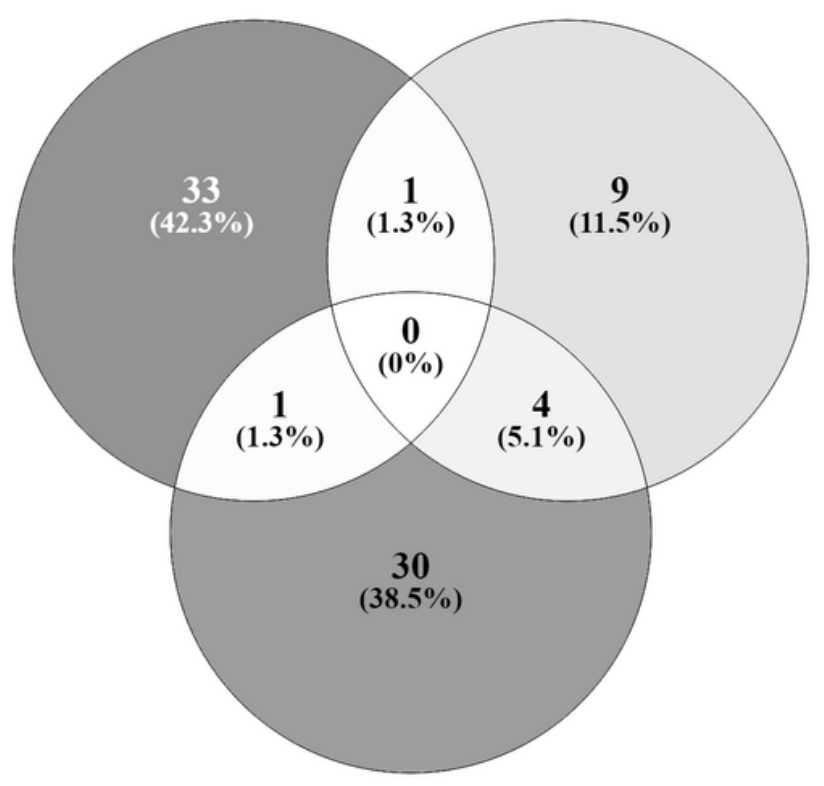

SM25

\section{Figure 1}

A) Left, up-regulated transcripts in treatments vs the control diet. B) Right, down-regulated transcripts in treatments vs the control diet. FM-P $=$ fish meal with $2 \%$ prebiotic, SM25 $=25 \%$ fish meal replacement with soybean meal, $\mathrm{SM} 25-\mathrm{P}=25 \%$ fish meal replacement with soybean meal and $2 \%$ prebiotic. 


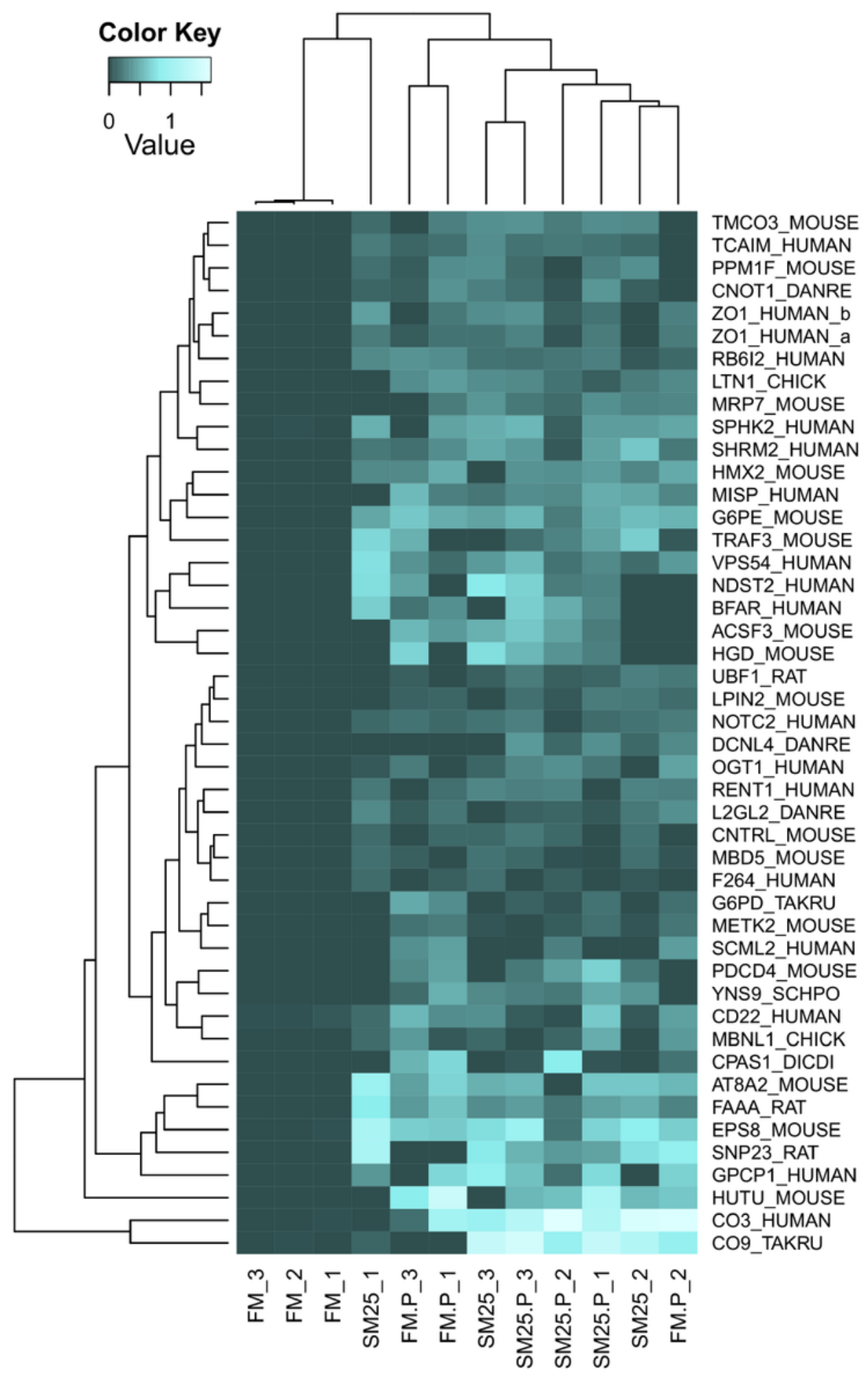

Figure 2

Sample clustering based on expression levels of up-regulated transcripts in treatments vs control diet, UniProt ID of the encoded protein is shown for each transcript. FM=control diet based on fish meal, FM$\mathrm{P}=$ fish meal with $2 \%$ prebiotic, $\mathrm{SM} 25=25 \%$ fish meal replacement with soybean meal, SM25-P=25\% fish meal replacement with soybean meal and $2 \%$ prebiotic. Values $=\log 10($ TPM $)$. 


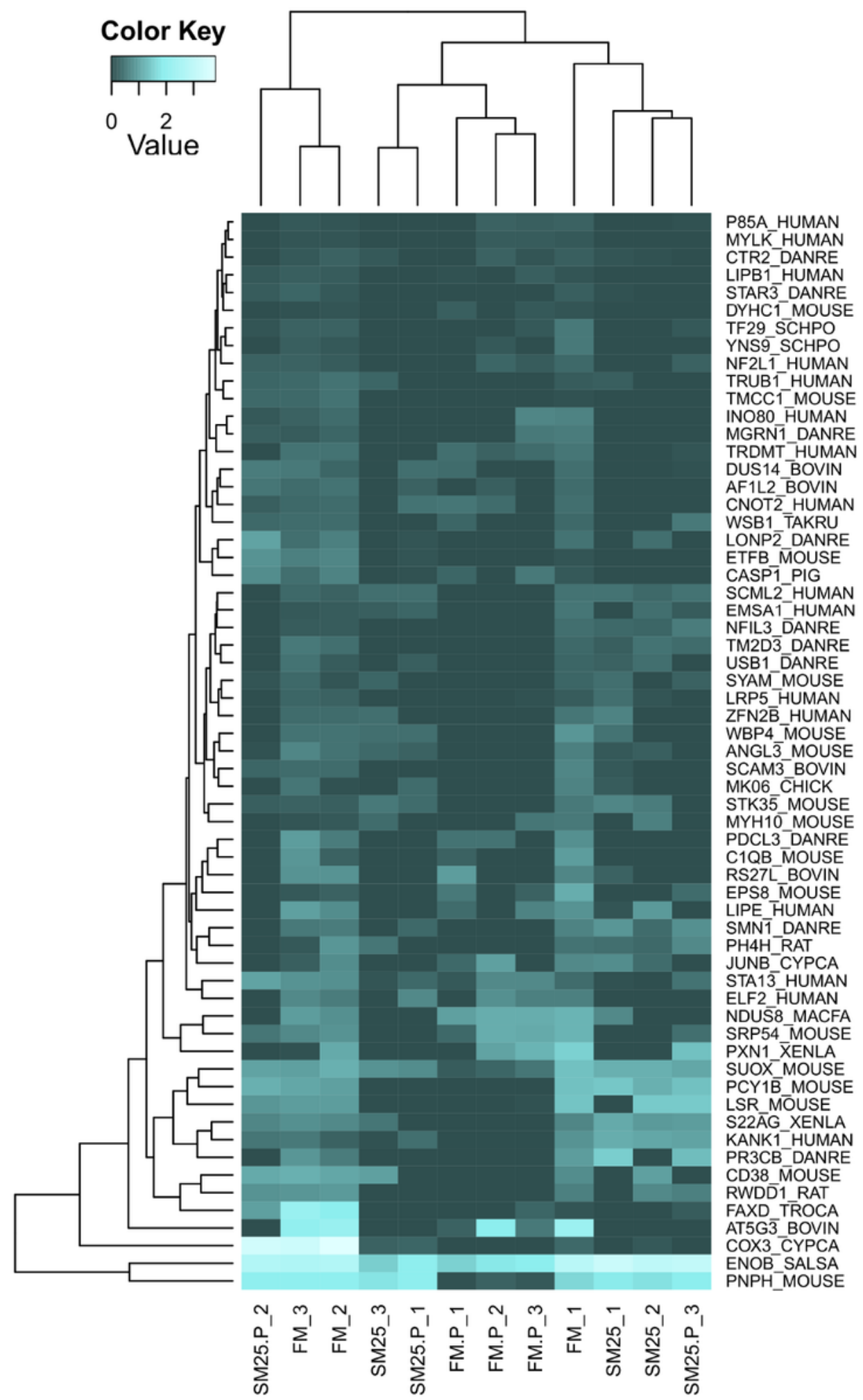

Figure 3

Sample clustering based on expression levels of down-regulated transcripts in treatments vs control diet, UniProt ID of the encoded protein is shown for each transcript. FM=control diet based on fish meal, FM$\mathrm{P}=$ fish meal with $2 \%$ prebiotic, $\mathrm{SM} 25=25 \%$ fish meal replacement with soybean meal, $\mathrm{SM} 25-\mathrm{P}=25 \%$ fish meal replacement with soybean meal and $2 \%$ prebiotic. Values $=\log 10($ TPM $)$. 


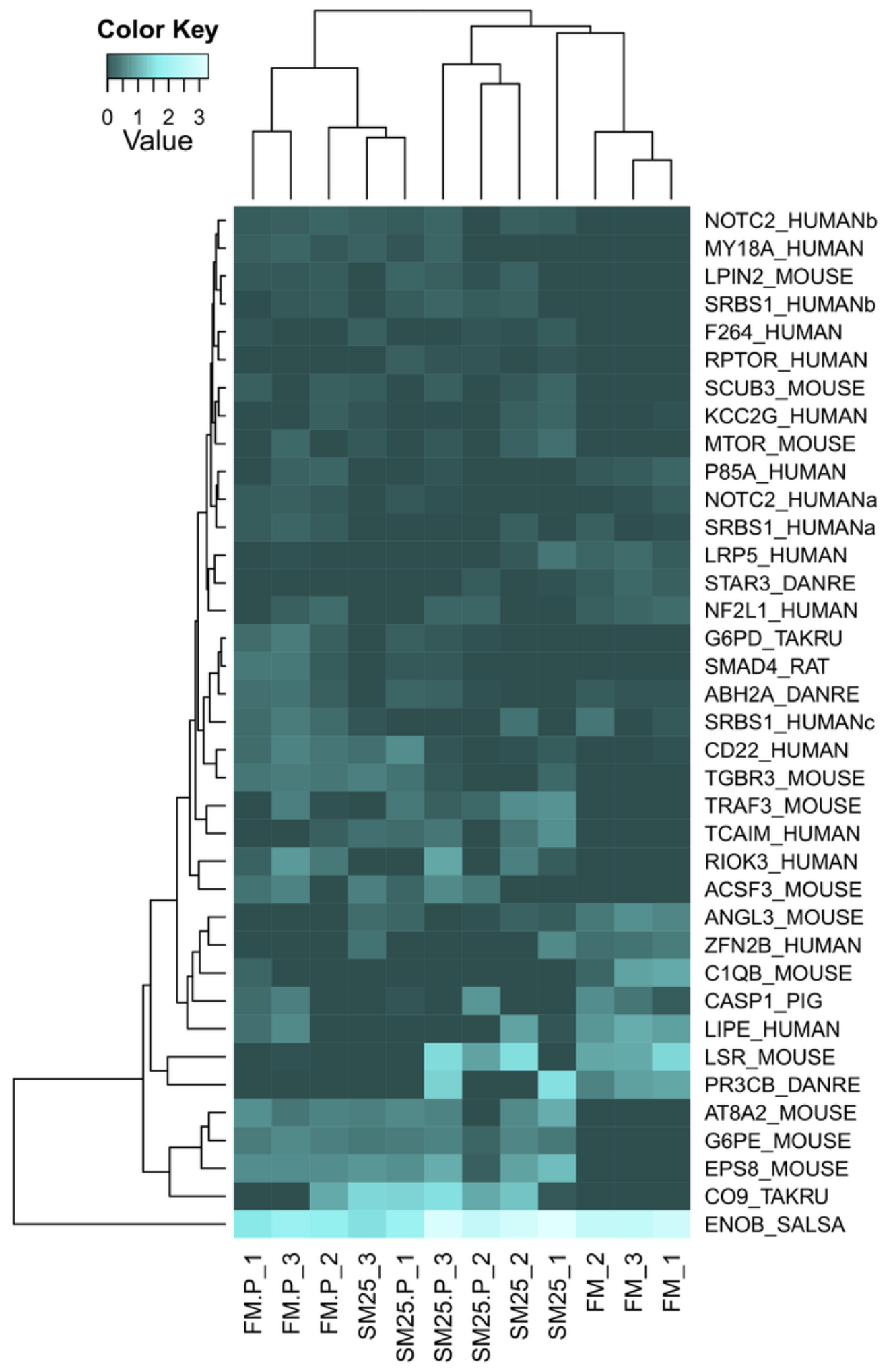

Figure 4

Sample clustering based on selected differentially expressed transcripts, UniProt ID of the encoded protein is shown for each transcript. FM=control diet based on fish meal, FM-P=fish meal with $2 \%$ prebiotic, SM25=25\% fish meal replacement with soybean meal, SM25-P=25\% fish meal replacement with soybean meal and $2 \%$ prebiotic. Values $=\log 10($ TPM $)$. 


\section{Supplementary Files}

This is a list of supplementary files associated with this preprint. Click to download.

- FigS1A.pdf

- FigS1B.pdf

- FigS1C.pdf

- FigS1D.pdf

- FigS1E.pdf

- Figs1F.pdf

- FigS1G.pdf 